\title{
PERBANDINGAN EFEK PENYEMBUHAN LUKA BAKAR ANTARA GEL EKSTRAK ETANOL DAUN AFRIKA (Gymnanthemum amygdalinum Del.)DENGAN GEL EKSTRAK ETANOL DAUN KELAPA SAWIT ( Elaeis guineensis Jacq.) SERTA KOMBINASINYA PADA KELINCI TAHUN 2019
}

\author{
Suventy Ginting, Zola Efa Harnis, Christica Ilsanna, Linta Meliala \\ Institut Kesehatan Deli Husada \\ e-mail :suventi123@gmail.com
}

\begin{abstract}
African leaves (Gymnanthemum amygdalinum Del.) And palm leaves (Elaeis guineensis Jacq.) Have secondary metabolites, namely alkaloids, steroids / terpenoids, flavonoids, tannins, and saponins in this study aimed to determine the effectiveness of healing burns. The extract was made by maceration method using $96 \%$ ethanol. This test used 3 rabbits, each of which had been burnt into 6 wound areas on the back of the rabbit. First group (positive control), second group (without treatment), third group gel with Arfika leaf ethanol extract concentration of 5\%, fourth group gel with palm ethanol extract concentration of $7.5 \%$, fifth group of groups gel with a combination of Arfika leaf ethanol extract concentration of $5 \%$ and $7.5 \%$ palm oil leaf ethanol extract The burns that have been made are smeared with as much test preparation as possible once a day. The next day the diameter of the wound was measured, then smeared with an adequate amount of gel. This is done until the diameter of the wound is equal to zero or the wound has been covered by new tissue. The results of testing the effectiveness of healing burns showed that all treatment groups had a faster recovery day compared to negative controls. The conclusion of this study is the combination of 5\% arfika ethanol extract gel and $7.5 \%$ oil palm leaf ethanol extract is the group with the fastest fastest day on the 19th day.
\end{abstract}

Keywords: Gymnanthemum amygdalinum Del., Elaeis guineensis Jacq., Burns.

\section{PENDAHULUAN}

Didalam kehidupan seharihari sering terjadi kecelakaan kecil yang berkaitan dengan kulit, misalnya kulit terkena air panas atau sebagainya sehingga menyebabkan kulit terkelupas atau luka bakar. Luka bakar semacam ini tidak dapat dianggap remeh, karena apabila dibiarkan akan menyebabkan infeksi.Perawatan luka bakar yang berkembang di masyarakat adalah dengan mengolesi minyak, mentega, pasta gigi, atau kecap pada area yang mengalami luka bakar Akan tetapitindakan tersebut dapat menghambat proses penyembuhan 
dan meningkatkan risiko terjadinya infeksi. Berdasarkan hal tersebut, diperlukan alternatif lain dalam penanganan luka bakar seperti memanfaatkan ekstrak buah tomat (Nova, 2007 ; Widianingtyas, d., dkk., 2014).

Ada 3 penyebab luka bakar, panas (termal), listrik, dan bahan kimia, semua mnyebabkan lesi kulit yang sama (Muttaqin dan Sari, 2011). Hilangnya lapisan kulit akibat luka bakar dapat menyebabkan terganggunya kemampuan tubuh untuk mengatur suhunya, sehingga seseorang dapat mengalami penurunan suhu tubuh pada beberapa jam pertama setelah mengalami luka bakar (Singer et al., 2014). Kerusakan jaringan akibat luka bakar bukan hanya terjadi pada permukaan kulit saja, juga jaringan bagian bawah kulit. Jaringan yang terbakar akan rusak, sehingga cairan tubuh bisa keluar melalui kapilee pembuluh darah pada jaringan yang mengalami pembengkakan akibat luka bakar (Guyton, 2007).

Bioplacenton merupakan salah satu obat topikal yang sering digunakan untuk mengobati luka bakar dalam bentuk Gel. Gel Bioplacenton digunakan untuk mengobati luka bakar atau luka lain dengan infeksi. Kandungan aktif dalam gel bioplacenton yang digunakan untuk pengobatan luka bakar adalah ekstrak plasenta ex bovine $10 \%$ dan neomisin sulfat $0,5 \%$. Ekstrak plasenta dipercaya dapat membantuk proses penyembuhan luka bakar dengan cara memicu pembentukan jaringan baru pada luka dan neomisin sulfat bekerja sebagai antibiotik untuk mencegah infeksi gram negatif (MIMS, 2009).

Menurut Chong et all (2008). Pengobatan herbal merupakan salah satu upaya pengobatan dan atau perawatan cara lain di luar ilmu kedokteran dan ilmu perawatan, pengobatan tradisional perlu dibina, dikembangkan dan diawasi agar dapat di pertanggung jawabkan manfaat dan keamanan ( Menkes RI,2008).

Berdasarkan penggunaan daun afrika dan daun kelapa sawit di masyarakat dan adanya efek farmakologis yang dihasilkan oleh senyawa-senyawa yang terkandung dalam daun afrika dan daun kelapa sawit, hal inilah yang mendasari pentingnya penulis untuk melakukan penelitian dengan judul "Perbandingan efek penyembuhan luka bakar antara gel ekstrak etanol daun afrika (Gymnanthemumamygdalinum del.) dengan gel ekstrak etanol daun kelapa sawit

Elaeisguineensisjacq.) serta kombinasinya pada kelinci.

\section{METODE PENELITIAN}

Metode penelitian yang digunakan dalam penelitian ini adalah bersifat eksperimental. Hewan percobaan yang digunakan Kelinci, dengan bb 1,5-2 kg. 


\subsection{Alat dan Bahan}

Alat-alat yang digunakan dalam penelitian ini meliputi alatalat gelas laboratorium, blender (national), jangka sorong, kandang kelinci, lempeng besi berdiameter 2,2 cm, mortir dan stamfer, neraca analitis (vibra), pH meter (HANNA), rotary evaporator (Heidolph Wb 2000), spuit $1 \mathrm{ml}$ (Terumo), stopwatch, termometer.

Bahan-bahan yang digunakan dalam penelitian ini adalah daun kelapa sawit (Elaeis guineensis Jacq.) dan daun afrika ( Vernonia amygdalina ) yang masih dalam keadaan baik dengan usia dewasa, tidak terlalu tua dan tidak terlalu muda. Bahan kimia yang digunakan adalah akuades, etanol 96\%, carbopol $\AA$ 940, lidokain $\mathrm{HCl}$, metil paraben, natrium klorida $0,9 \%$, sorbitol, TEA.

\subsection{Tempat penelitian}

Pembuatan ekstrak di lakukan di laboratorium fitokimia, pembuatan sediaan gel di lakukan di Laboratorium Teknologi Sedian Farmasi, dan pengujian efektivitas penyembuhan luka bakar di lakukan di laboratorium Farmakologi Institut Kesehatan Deli Husada Delitua.

\subsection{Waktu penelitian}

Penelitian dilakukan di Fakultas Farmasi Institut Kesehatan Deli Husada Deli tua pada bulan Januari - April 2019.

\section{PROSEDUR PENELITIAN}

\subsection{Pembuatan ekstrak etanol daun afrika dan kelapa sawit}

Serbuk simplisia diekstraksi dengan cara maserasi menggunakan pelarut etanol $96 \%$. Sebanyak $300 \mathrm{~g}$ serbuk simplisia dimasukkan kedalam suatu bejana, dituangi dengan 2,75 L (75 bagian) etanol, ditutup. Dibiarkan selama 5 hari terlindung dari cahaya sambil sering diaduk lalu diserkai. Ampas dimaserasi dengan etanol secukupnya hingga diperoleh $3 \mathrm{~L}$ (100 bagian). Pindahkan maserat ke dalam bejana tertutup, dibiarkan ditempat sejuk terlindung dari cahaya selama 2 hari, enap tuangkan. Pemekatan ekstrak dilakukan dengan alat rotary evaporator pada suhu $\pm 500 \mathrm{C}$ hingga diperoleh ekstrak kental, selanjutnya di freeze dryer pada suhu $-400 \mathrm{C}$ hingga diperoleh ekstrak kering (Depkes RI, 1979).

\subsection{Pembuatan basis gel}

Pembuatan basis gel menurut Soeratri (2004), adalah sebagai berikut:

R/ Carbopol 3gr

Metil paraben 0,2 gr

Sorbitol 14gr

TEA $0,8 \mathrm{gr}$

Aqudest ad $100 \mathrm{gr}$

Cara pembuatan: Carbopol dikembangkan emnggunakan aquadest (Campuran 1).Ekstrak di larutkan dengan sorbitol dan di campur dengan metil paraben yang 
telah dilarutkan air panas menggunakan batang pengaduk hingga homogen (campuran 2). Campuran 2 di masukkan ke dalam campuran 1 dan di homogenkan kemudian ditambahkan sisa aquadest. setelah homogen, kedalam campuran tadi ditambahkan TEA dan diaduk hingga homogen.

\subsection{Pengujian efektivitas}

\section{luka bakar}

Pengujian ini digunakan 3 ekor kelinci yang masing-masing telah di buat luka bakar menjadi 6 area luka pada punggung kelinci

I : kontrol positif bioplacenton )

II : kontrol negatif (tanpa perlakuan )

III : gel dengan EEDA konsentrasi $5 \%$

IV : gel dengan EEDKS konsentrasi 7,5\%

V: gel dengan campuran EEDA konsentrasi $5 \%$ dan EEDKS $7,5 \%$

Luka bakar yang telah dibuat diolesi dengan sediaan uji sebanyak secukupnya sekali sehari. Hari berikutnya diameter luka diukur, lalu diolesi gel secukupnya. Hal ini dilakukan sampai diameter luka sama dengan nol atau luka telah tertutup jaringan baru.

\subsection{Komposisi formula}

Sediaan gel yang dibuat menggunakan basis gel Carbopol dalam 3 formula dengan komposisi masing-masing 100 gr yang terlihat pada Tabel 3.1 di bawah:

Tabel 3.1 Komposisi formula gel EEDA dan EEDKS serta kombinasinya

\begin{tabular}{ccccc}
\hline $\mathrm{N}$ & Formula & \multicolumn{3}{c}{ KOMPOSISI } \\
0 & & $\begin{array}{c}\text { Basis } \\
\text { gel } \\
(\mathrm{gr})\end{array}$ & $\begin{array}{c}\text { EEDA } \\
\text { (gr) }\end{array}$ & $\begin{array}{c}\text { EEDK } \\
\text { (gr) }\end{array}$ \\
\hline 1. & F1 & 95 & 5 & 0 \\
2. & F2 & 92,5 & 0 & 7,5 \\
\hline 3. & F3 & 87,5 & 5 & 7,5
\end{tabular}

Keterangan: F1: gel EEDA 5\%, F2: gel EEDKS 7,5\%, F3: Kombinasi gel EEDA $5 \%+$ EEDKS 7,5 \%

\subsection{Pengujian sediaan gel terhadap penyembuhan luka bakar}

Menurut Suratman at al (1996) Kelinci terlebih dahulu dicukur bagian punggungnya seluas $240 \mathrm{~cm} 2(12 \times 20 \mathrm{~cm})$, dan daerah punggung dibagi menjadi 6 area luka kemudian dibuat luka bakar pada kelinci dengan cara menempelkan lempeng besi berdiameter 2,2 cm yang telah dipanaskan dalam air mendidih dengan suhu $1000 \mathrm{C}$ selama 15 menit dan ditempelkan pada punggung kelinci yang telah dianastesi dengan lidokain HClselama 15 detik, selanjutnya diameter luka diukur dengan menggunakan jangka sorong dan dianggap sebagai diameter hari ke0 . Selanjutnya pada kulit yang melepuh atau yang mengalami luka bakar, dioleskan sediaan gel 
EEDAatau EEDKS satu kali sehari secara merata pada luka bakar untuk semua kelompok. Pengamatan dilakukan secara visual setiap hari sampai luka bakar sembuh dengan mengukur pengurangan diameter luka menggunakan jangka sorong. Luka dianggap sembuh jika diameter luka sama dengan nol.

\section{HASIL dan PEMABAHASAN}

\section{Identifikasi sampel}

Hasil identifikasi sampel dilakukan di Herbarium Medanese (FMIPA) Universitas Sumatera Utara, Medan, sampel yang diperoleh adalah daun afrika (Gymnanthemum amygdalinum Del.), famili Asteraceae, dan daun kelapa sawit (Elaeis guineensis Jacq.), famili Arecaceae.

\section{Pengambilan daun dan pengeringan daun}

Sampel yang diperoleh dipisahkan dari tulang daunnya, dicuci hingga bersih, ditiriskan, ditimbang, lalu dikeringkan di bawah cahaya lampu pijar kuning ( tdak di bawah sinar matahari). Selanjutnya sampel dihaluskan atau diserbukkan menggunakan blender, dimasukkan ke dalam wadah plastik, kemudian disimpan pada suhu kamar.Hasil pengambilan daun adalah daun afrika dan daun kelapa sawit yang segar dan dipetik langsung dari pohonnya dengan berat daun afrika $5764 \mathrm{gr}$ daun afrika basah diperoleh 795gr serbuk simplisia, dan daun kelapa sawit
4875 gr daun kelapa sawit basah diperoleh 867 gr serbuk simplisia.

\section{Ekstraksi serbuk simplisia}

Pada penelitian ini menggunakan zat aktif ekstrak daun afrika (Gymnanthemum amygdalinum Del.) dan ekstrak daun kelapa sawit ( Elaeis guineensis Jacq.) yang diekstraksi mengunakan penyari etanol $96 \%$. Etanol dipertimbangkan sebagai penyari karena lebih selektif dari pada air. Memiliki beberapa kelebihan lain yaitu tak beracun, netral, absorbsi baik, bercampur dengan air pada segala perbandingan.

Etanol adalah penyari yang bersifat universal yaitu dapat melarutkan senyawa polar maupun senyawa nonpolar (Voight, 1995). Etanol $96 \%$ yang tidak banyak mengandung air dibandingkan etanol 70\%, sehingga resiko ekstrak ditumbuhinya jamur atau kapang lebih kecil. Etanol 96\% juga dipilih sebagai pelarut karena senyawa yang terkandung pada daun afrika yaitu: alkaloid, triterpenoid, flavonoid dan saponin, tanindan kelapa sawit yaitu:ada yang bersifat polar dan nonpolar.

Proses ekstraksi yang digunakan adalah maserasi, di mana hasil maserat yang didapatkan dibebas etanolkan dengan proses penguapan penyari dalam alat rotavapor (rotary evaporation). Dibebas etanolkan agar mendapatkan ekstrak yang lebih murni. 


\begin{abstract}
Diketahui bobot simplisia awal keseluruhan daun afrika (Gymnanthemum amygdalinum Del.) sebanyak 500 gram lalu didapatkan bobot total ekstrak kering sebanyak 34,25 gr, dan bobot simplisia awal keseluruhan ( Elaeis guineensis Jacq.)sebanyak 500 gram lalu didapatkan bobot total ekstrak kering daun kelapa sawit sebanyak 25,52 gr.
\end{abstract}

\section{Karakteristik Simplisia}

Pemeriksaan karakteristik simplisia meliputi penetapan kadar air, penetapan kadar sari larut air, penetapan kadar sari larut etanol, penetapan kadar abu total, dan penetapan kadar abu tidak larut asam. Penetapan kadar sari larut dalam air dan etanol dilakukan untuk memberikan gambaran awal jumlah senyawa yang dapat tersari dengan pelarut air dan etanol. Penetapan kadar abu total dilakukan dengan tujuan memberikan gambaran kandungan mineral internal dan eksternal yang berasal dari proses awal sampai terbentuknya simplisia yang berkaitan dengan senyawa organik maupun anorganik yang diperoleh secar internal dan eksternal. Kadar abu tidak larut asam bertujuan untuk mengetahui jumlah abu yang diperoleh dari faktor eksternal seperti pasir atau tanah silikat.

\section{Uji Stabilitas Sediaan Gel}

Uji stabilitas sediaan gel meliputi pemeriksaan stabilitas fisik sediaan, pemeriksaan homogenitas, dan $\mathrm{pH}$ sediaan yang dilakukan selama 28 hari penyimpanan. Pengamatan dilakukan pada suhu kamar, yaitu pada hari ke-0, 7, 14, 21, dan 28 hari (Abdassah, dkk., 2009). Dalam penelitian ini dilakukan uji stabilitas fisik sediaan, pemeriksaan homogenitas, dan $\mathrm{pH}$ sediaan dengan menujukkan stabilitas fisik sediaan pada hari ke 1 hingga ke 28 dengan bentuk semi padat, warna hitam, bau Khas, homogenitas yang homogen dan $\mathrm{pH}$ sediaan tetap pada 5,5

\section{Penyembuhan Luka Bakar}

Pengobatan luka bakar dengan menggunakan sediaan gel ekstrak ekstrak daun afrika (Gymnanthemum amygdalinum Del.) dan ekstrak daun kelapa sawit ( Elaeis guineensis Jacq.) dilakukan secara topikal dengan frekuensi satu kali hingga terjadi kesembuhan pada luka bakar. Terjadinya kesembuhan pada luka bakar ditandai dengan merapatnya kulit, kekeringan luka dan karopeng di sekitar luka terkelupas dengan sendirinya. Pada penelitian, pengamatan dilakukan hingga luka tertutup sempurna. Dimana ratarata waktu penyembuhan luka untuk gel ekstrak etanol daun afrika $5 \%$ yaitu hari ke- 23 untuk gel ekstrak etanol daun kelapa sawit $7,5 \%$ yaitu hari ke-24 untuk gel kombinasi ekstrak daun afrika dan kelapa sawit yaitu hari ke-19 dan untuk kontrol negatif hari ke-25 sedangkan untuk gel Bioplacenton $\AA$ yaituhari ke-20. Hasil uji penyembuhan luka $100 \%$ menunjukkan bahwa gel ekstrak 
kombinasi daun afrika dan kelapa satwit waktu penyembuhan lukanya (luka tertutup 100\%) sangat berbeda nyata berdasarkan ratarata kecepatan penutupan luka $100 \%$ dengan gel ekstrak etanol daun afrika $5 \%$ dan gelekstrak etanol daun kelapa sawit 7,5\%. Sedangkan kontrol negatif menunjukkan perbedaan sangat nyata dengan gel ekstrak etanol daun afrika $5 \%$ dan gel ekstrak etanol daun kelapa sawit 7,5\%

\section{Hasil Pengamatan Pada Penyembuhan Luka Bakar}

Pengamatan luka kelinci dilakukan selama25 hari dan dibagi menjadi tiga kelompok dimana masing-masing kelompok terdiri dari 3 ekor kelinci. Hasil penyembuhan luka bakar pada masing-masing kelompok dapat dilihat pada tabel dibawah ini:

Tabel 4.1 Hasil Pengamatan Pada Penyembuhan Luka Bakar

\begin{tabular}{cccccc}
\hline Ha & & & \multicolumn{3}{c}{ EED } \\
ri & & \multicolumn{3}{c}{ EED } & KS \\
Ke & $\begin{array}{c}\text { Positiv } \\
-\end{array}$ & e & $\begin{array}{c}\text { vegati } \\
\text { A }\end{array}$ & $\begin{array}{c}7,5 \\
5 \%\end{array}$ & $\begin{array}{c}\text { Kombi } \\
\text { nasi }\end{array}$ \\
\hline 1 & 2,2 & 2,2 & 2,2 & 2,2 & 2,2 \\
2 & 2,2 & 2,2 & 2,2 & 2,2 & 2,2 \\
3 & 1,94 & 2,16 & 1,97 & 2,09 & 1,86 \\
4 & 1,88 & 2,10 & 1,93 & 1,97 & 1,82 \\
5 & 1,82 & 2,01 & 1,89 & 1,92 & 1,77 \\
6 & 1,81 & 1,95 & 1,85 & 1,9 & 1,73
\end{tabular}

\begin{tabular}{cccccc}
7 & 1,72 & 1,93 & 1,8 & 1,82 & 1,67 \\
8 & 1,68 & 1,86 & 1,75 & 1,78 & 1,61 \\
9 & 1,61 & 1,81 & 1,68 & 1,72 & 1,56 \\
10 & 1,57 & 1,77 & 1,64 & 1,67 & 1,52 \\
11 & 1,50 & 1,74 & 1,59 & 1,63 & 1,45 \\
12 & 1,45 & 1,68 & 1,50 & 1,56 & 1,37 \\
13 & 1,35 & 1,63 & 1,43 & 1,48 & 1,27 \\
14 & 1,29 & 1,57 & 1,36 & 1,41 & 1,16 \\
15 & 1,21 & 1,53 & 1,27 & 1,35 & 0,94 \\
16 & 1,01 & 1,48 & 1,15 & 1,25 & 0,76 \\
17 & 0,73 & 1,41 & 0,83 & 1,13 & 0,25 \\
18 & 0,53 & 1,35 & 0,75 & 0,93 & 0,16 \\
19 & 0,14 & 1,23 & 0,73 & 0,84 & 0 \\
20 & 0 & 1,17 & 0,42 & 0,71 & 0 \\
21 & 0 & 0,62 & 0,22 & 0,46 & 0 \\
22 & 0 & 0,41 & 0,13 & 0,38 & 0 \\
23 & 0 & 0,20 & 0 & 0,03 & 0 \\
24 & 0 & 0,15 & 0 & 0 & 0 \\
\hline 25 & 0 & 0 & 0 & 0 & 0
\end{tabular}

Pada penelitian, pengamatan dilakukan hingga luka tertutup sempurna. Dimana rata-rata waktu penyembuhan luka untuk gel ekstrak etanol daun afrika $5 \%$ yaitu hari ke- 23 untuk gel ekstrak etanol daun kelapa sawit $7,5 \%$ yaitu harike-24 untuk gel kombinasi ekstrak daun afrika dan kelapa sawit yaitu hari ke-19 dan untuk kontrol negatif hari ke-25 
sedangkan untuk gel Bioplacenton $\AA$ yaitu hari ke-20. Hasil uji penyembuhan luka $100 \%$ menunjukkan bahwa gel ekstrak kombinasi daun afrika dan kelapa satwit waktu penyembuhan lukanya (luka tertutup $100 \%$ ) sangat berbeda nyata berdasarkan ratarata kecepatan penutupan luka $100 \%$ dengan gel ekstrak etanol daun afrika $5 \%$ dan gel ekstrak etanol daun kelapa sawit 7,5\%. Sedangkan kontrol negatif menunjukkan perbedaan sangat nyata dengan gel ekstrak etanol daun afrika $5 \%$ dan gel ekstrak etanol daun kelapa sawit 7,5\%

Gambar 4.1 Grafik rata- rata Penyembuhan luka bakar

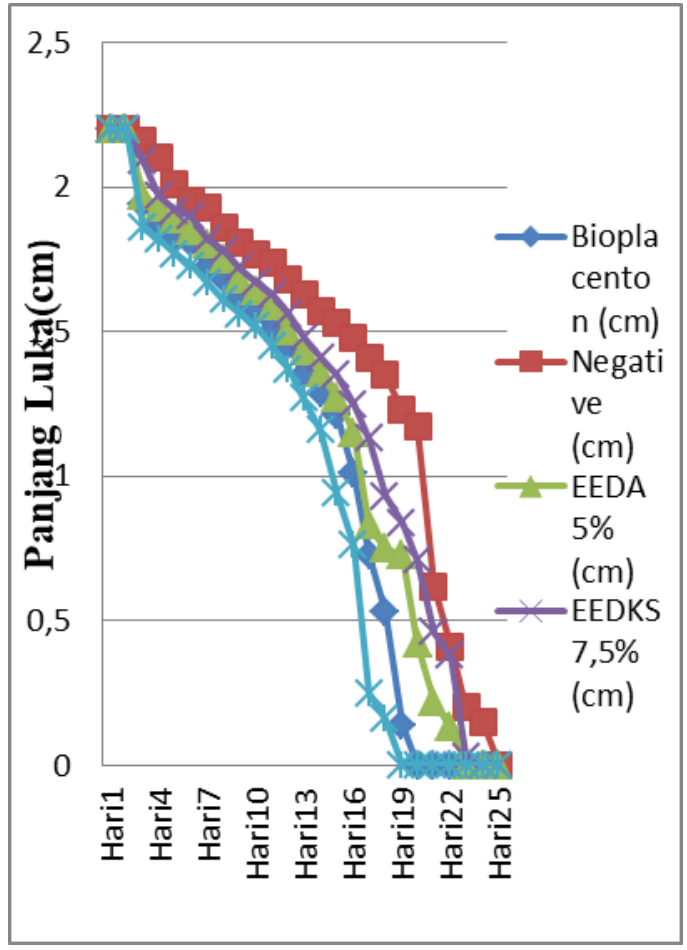

\section{Analisis Data}

Hasil analisa data statistik menunjukkan bahwa data pengukuran luka bakar pada hewan uji adalah homogen ( dapat diterima karena menunjukkan nilai sig >0,05), Hasil analisa data statistik juga menunjukkan bahwa semua dosis kombinasi EEDA dan EEDKS dapat menurunkan diameter luka bakar pada hewan uji secara signifikan karena menunjukkan nilai sig $<0,05$

\section{KESIMPULAN}

Dari hasil penelitian yang telah dilakukan dapat disimpulkan, sebagai berikut :

A. Kombinasi ekstrak etanol daun afrika (EEDA) dan ekstrak etanol daun kelapa sawit (EEDKS) dapat di formulasikan menjadi sediaan gel

B. EEDA dan EEDKS memiliki efektivitas penyembuhan luka bakar yang sama

C. Kombinasi EEDA dan EEDKS memiliki efektifitas penyembuhan luka bakar yang lebih baik dari pada tanpa kombinasi

\section{DAFTAR PUSTAKA}

Chong, K.H., Zuraini, Z., Sasidharan, S., Devi, K., Latha, Y.L., dan Ramanathan, S. (2008). Antimicrobial of Elaeis guineensis leaf. Pharmacology online. 3: 379386.

Departemen Kesehatan RI, (1979). Farmakope Indonesia, Edisi III, DepartemenKesehatan Republik Indonesia, Jakarta, p. 96. a. 
Departemen Kesehatan, RI. (2008).

Farmakope herbal Indonesia,

Derektorat Jendral

Pengawasan Obat dan

Makanan, Jakarta, Indonesia.

Guyton, A. C., dan Hall, J. E. (2007). Buku Ajar Fisiologi Kedokteran. Edisi 11. Jakarta: Penerbit Buku Kedokteran EGC. Halaman 862.

MIMS, (2009). MIMS Indonesia Petunjuk Konsultasi. Jakarta : PT Bhuana Ilmu Populer. Halaman 356.

Muttaqin, A ., dan Sari, K. (2011). Asuhan Keperawatan Gangguan Sistem Integumen. Jakarta: Penerbit Salemba Medika. Halaman 1-4, 200201.

Singer AJ, Taira, BR, Lee CC. (2014). Thermal burns. Dalam: Rosen's emergency medicine - concepts and clinical practice. Elsevier Inc. hlm: 808-817.

Soeratri, W. (2004). Pengaruh Penambahan Asam Glikolat Terhadap EfektivitasSediaan Tabir Surya Kombinasi Anti UV-A dan Anti UV-B Dalam Basis Gel. Surabaya: Majalah Farmasi Airlangga. 4(3): 76.

Suratman, Sumiwi, S. S., and Gozali, D., (1996). pengaruh Ekstrak tanaman dalam bentuk salep, krim, dan jelly terhadap penyembuhan luka bakar, Cermin dunia kedokteran, 108:131-136.

Abdassah, M., Rusdiana, T., Subghan, A., Hidayati, G.
(2009). Formulasi Gel Pengelupas Kulit Mati yang Mengandung Etil Vitamin C dalam Sistem Penghantaran Macrobead. Jurnal Ilmu Kefarmasian Indonesia. 107.

Voigt, R. (1995). Buku Pelajaran Teknologi Farmasi. Cetakan Kedua. Yogyakarta: UGM Press. Halaman 335, 565, 568.

Widianingtyas, D., Wihastuti, T. S. dan Setijowati, N., Pengaruh Perawatan Dengan Ekstrak Pegagan Dalam Mempercepat Penyembuhan Luka Bakar Derajat 2 Dangkal Pada Tikus Putih Strain Wistar, Volume 1, Majalah Kesehatan FKUB, Jakarta. 